\title{
Resistance in Some Japonica Rice Cultivars to Rice Tungro Spherical Virus
}

\author{
Tokio ImBE $^{1)}$, HabiBuddin Hashim ${ }^{2)}$, Mabito Iwasaki $^{3)}$ and Toshihiro Omura ${ }^{4)}$ \\ 1) Tropical Agriculture Research Center, Tsukuba, 305 \\ 2) Malaysian Agricultural Research and Development Institute, Kepala \\ Batas, 13200 Seberang Prai, Malaysia \\ 3) Shikoku National Agricultural Experiment Station, Zentsuji, 765 \\ 4) National Agriculture Research Center, Tsukuba, 305
}

\begin{abstract}
Four rice waika virus (RWV)-resistant japonica rice cultivars, Aichi Asahi, Kimmaze, Nishikaze and Saikai 139, and RWV-susceptible cultivar Reiho were tested for their resistance to rice tungro spherical virus (RTSV). Seedlings of the cultivars were artificially inoculated with RTSV plus rice tungro bacilliform virus (RTBV) by viruliferous green leafhopper, Nephotettix virescens (GLH), and virus infections were determined by the enzymelinked immunosorbent assay (ELISA). Seedling infection with RTSV was low in the four RWV-resistant cultivars in contrast with RTSV infection in Reiho, which was as high as in susceptible check cultivar Taichung Native 1 (TN1). The antibiosis test showing that all the four cultivars were susceptible to the vector GLH indicates that the low RTSV infection in the cultivars were due to their resistance to RTSV infection. Furthermore, the low ELISA value for RTSV of the four cultivars suggests that the cultivars were also resistant to RTSV multiplication. All these cultivars were susceptible to RTBV infection and its multiplication. These results support the conclusions of earlier reports suggesting that RWV was identical with or closely related to RTSV. Among other 17 cultivars tested, those reported to be highly resistant to RWV (ShIMURA et al. 1978) were found to be resistant also to RTSV infection. The lineage study on the four RWV-resistant cultivars showed that the RTSV resistance of these cultivars was derived from that of traditional Japanese cultivar Takenari. The result that RWV-resistant cultivars tested were also resistant to RTSV indicates that RWV-resistant cultivars could become outstanding new gene sources for RTSV resistance of japonica cultivars, because some of the RWV-resistant cultivars have good agronomical traits. On the other hand, RTSV-resistant indica cultivars, such as those bred at the International Rice Research Institute (Hibino et al. 1988) could become new gene sources for resistance to rice waika disease.
\end{abstract}

KEY WORDS: Oryza sativa, japonica, resistance, tungro, rice, ELISA.

\section{Introduction}

Tungro is the most important virus disease of rice in South and Southeast Asia. In Malaysia, the disease is known as "penyakit merah" of which severe epidemics occurred during the period of 1981 to 1983 (ABU KASSIM and HaBIBUdDIN 1986). Tungro-resistant cultivar IR42 has been planted in farmers' fields and used as a gene source for tungro resistance in the rice breeding program. However, it had a high level of seedling infection with tungro when it was inoculated by a colony of the green leafhopper, Nephotettix virescens (GLH) that have been bred and survived on IR42 (HABIBUDDIN et al. 1990). This fact indicates that the tungro resistance in IR42 is due to its resistance against GLH as reported by KoBAyAshi et al. (1983). These results suggest that IR42 could be damaged by tungro due

Received April 4, 1993.

Accepted September 13, 1993. 
to development of GLH populations which overcome the resistance once planted over a large area and for a long period of time. For the reasons mentioned above, source of resistance to other than GLH is desired to be identified.

Rice tungro disease is caused by a complex of two viruses, rice tungro bacilliform virus (RTBV) and rice tungro spherical virus (RTSV) (SArTo et al. 1981). RTBV causes the distinct symptoms of tungro disease, whereas RTSV alone does not cause distinct symptoms (Hibino et al. 1978). The symptoms become more pronounced when the plants are doubly infected with RTBV and RTSV.

The viruses are transmitted efficiently by GLH in a semipersistent manner (LING 1972). Hibino et al. (1978) reported that RTBV was transmitted concomitantly only when RTSV had been acquired previously or simultaneously by GLH. This facts indicates that RTBV, a major cause of tungro symptoms, can never be transmitted without the aid of RTSV as a "helper" in its transmission, and hence RTSV is considered to play an important role in the epidemiology of tungro.

According to the above mentioned characteristics of the disease, three types of resistances are expected to be effective for controlling rice tungro disease, namely, resistance to vector insect; resistance to RTBV; resistance to RTSV. In the present study, we aimed at developing a resistance to RTSV.

Based on the similarity in morphological characteristics (NISHI et al. 1975), sedimentation coefficient values and serological properties of the particles (SArto 1977), and the presence of common vector insects (HIRAo and Inove 1978), RTSV is considered to be the same as or closely related to rice waika virus (RWV) which was responsible for the 1971-1974 epidemic of waika disease in Kyushu, southern Japan. This assumption was further supported by the transmission study showing that RWV also act as a helper virus for RTBV transmission by GLH (HiBINo 1983).

This paper describes resistances to RTSV of some Japanese cultivars that were reported to be resistant to RWV (Shrmura et al. 1978).

\section{Materials and Methods}

Four RWV-resistant Japanese cultivars, Aichi Asahi, Kimmaze, Nishikaze, and Saikai 139, and a susceptible cultivar Reiho were tested for their response to tungro infection and antibiosis to GLH. IR42 served as the GLH-resistant check and Taichung Native 1 (TN1) as the susceptible check.

The lineage of RTSV (RWV) resistance in Japanese cultivars and comparison between RWV resistance and seedling infection with RTSV were investigated by testing 17 Japanese cultivars other than those stated above.

Tungro-infected TN1 plants maintained at Malaysian Agricultural Research and Development Institute (MARDI) were used as the inoculum source. A GLH colony which has been maintained on TN1 plants at MARDI was used in the antibiosis and tungro inoculation tests.

Testing methods for tungro resistance and GLH antibiosis were as follows: 


\section{1) Tungro resistance}

a. Virus Infection Rate: GLH adults were allowed an acquisition feeding on tungro infected (RTBV plus RTSV infected) TN1 plants for two days. Twenty-five seedlings at seven days after sowing (DAS) were inoculated in a mylar cage by confining for one day with 38 viruliferous GLH adults (1.5 GLH/seedling). Each cultivar had two replications except in the lineage test where the 17 cultivars were tested without replication. Three or four weeks after the inoculation (WAI), a whole of each inoculated plant was crushed with $1.25 \mathrm{~m} l$ of $\mathrm{pH} 7.0,0.1 \mathrm{M}$ phosphate buffer (PB) in a "Combined leaf and germ juice press" (MEKU, West Germany). Extract was separately tested for the presence of the viruses with the enzyme-linked immunosorbent assay (ELISA).

b. Virus Concentration: Three weeks after sowing, 30 seedlings of each cultivar were separately inoculated by exposing to five viruliferous GLH adults in a glass cylinder with a net on the top. At three WAI, the penultimate or top expanding leaf was collected from each inoculated seedling. Approximately $0.083 \mathrm{~g}(+5 \%)$ tissues from each leaf sample was crushed with $1.25 \mathrm{~m} l$ of $\mathrm{PB}(\times 15)$ and the extract was subjected to ELISA. Absorbance at $405 \mathrm{~nm}$ was measured for each sample in a ELISA reader (EAR400, SLT, Austria). Extract of RTBV plus RTSV infected TN1 leaves served as the standard. Eight wells of each microplate were filled with the standard extract for adjustment of absorbance values among microplates.

c. ELISA: The double antibody-sandwich ELISA (CLARK and AdAMS 1977) using the procedures described by TAKAHAshi et al. (1991) was employed for the detection of RTBV and RTSV. Antisera used were prepared according to the methods described by OMURA et al. (1983).

\section{2) Antibiosis to GLH}

Seedlings at seven DAS were separately caged with five first- or second-instar GLH nymphs. The mortality of nymphs was recorded three days after caging. Ten seedlings were tested for each cultivar.

\section{Results}

Four RWV-resistant cultivars, Aichi Asahi, Kimmaze, Nishikaze and Saikai 139 had RTSV infections significantly less than those Reiho and TN1 had (Table 1). Infection rates with RTBV in these four cultivars were as high as those in Reiho and TN1. In the antibiosis test, the four RWV-resistant cultivars and Reiho were susceptible to GLH as TN1. IR42 showed low infection rates with both RTBV and RTSV, probably due to its resistance to GLH (KoBayashi et al. 1983).

In ELISA, the four RWV-resistant cultivars showed absorbance value for RTSV lower than that of the susceptible cultivars (Table 2). These results indicate that RTSV concentration in infected plants of RWV-resistant cultivars is lower than that in Reiho and TN1, based on the concept that the absorbance value is proportional to the virus concentration (C $\mathrm{LARK}$ and Adams 1977). The absorbance values for RTBV or RTSV in Reiho was as high as in TN1.

Some other RWV-resistant cultivars (ShimuRA et al. 1978) were tested for RTSV 
Table 1. Resistance of four RWV-resistant cultivars to RTSV infection and to GLH

\begin{tabular}{|c|c|c|c|c|c|c|c|}
\hline \multirow[t]{2}{*}{ Cultivar } & \multicolumn{4}{|c|}{$\begin{array}{l}\text { Plants (\%) that had } \\
\text { infection with }{ }^{1)}\end{array}$} & \multicolumn{2}{|c|}{$\begin{array}{l}\text { Percentage of } \\
\text { infection with }\end{array}$} & \multirow{2}{*}{$\begin{array}{c}\text { Antibiosis } \\
\text { to GLH }\end{array}$} \\
\hline & BS & B & $S$ & $\mathrm{~N}$ & RTBV & RTSV & \\
\hline Aichi Asahi & $21 b^{2)}$ & 62 & 0 & 7 & $83 a$ & $21 \mathrm{~b}$ & $4.9^{3)}$ \\
\hline Kimmaze & $30 \mathrm{~b}$ & 68 & 0 & 2 & $98 \mathrm{a}$ & $30 \mathrm{~b}$ & 4.9 \\
\hline Nishikaze & $25 \mathrm{~b}$ & 73 & 0 & 2 & $98 \mathrm{a}$ & $25 b$ & 5.0 \\
\hline Saikai 139 & $11 b$ & 87 & 0 & 0 & $98 \mathrm{a}$ & $11 \mathrm{~b}$ & 4.7 \\
\hline Reiho & $90 \mathrm{a}$ & 10 & 0 & 0 & $100 \mathrm{a}$ & $90 \mathrm{a}$ & 4.3 \\
\hline IR42 & $6 \mathrm{~b}$ & 16 & 10 & 68 & $23 \mathrm{~b}$ & $17 \mathrm{~b}$ & 0.0 \\
\hline TN1 & $94 a$ & 6 & 0 & 0 & $100 \mathrm{a}$ & $94 \mathrm{a}$ & 5.0 \\
\hline
\end{tabular}

${ }^{1)}$ BS: both RTBV and RTSV, B: RTBV only, S: RTSV only, N: Not infected

${ }^{2)}$ Percentages of infected plants determined by ELISA. Means of two replications. All data followed by a common letter are not significantly different at the $5 \%$ level by DunCAN's Multiple Range Test with arcsine transformed data.

3) Number of surviving nymphs among 5 nymphs confined in the GLH antibiosis test. Average of ten replications.

Table 2. Relative concentration of RTBV and RTSV in infected plants of four RWV-resistant cultivars

\begin{tabular}{lccccc}
\hline \multirow{2}{*}{ Cultivar } & \multicolumn{2}{c}{ Infection rate $(\%)$} & & \multicolumn{2}{c}{ Absorbance at $405 \mathrm{~nm}$} \\
\cline { 2 - 3 } & RTBV & RTSV & & RTBV & RTSV \\
\hline Aichi Asahi & 93 & 3 & & $89^{1)}$ & $46^{1)}$ \\
Kimmaze & 100 & 10 & & 73 & 34 \\
Nishikaze & 100 & 7 & & 93 & 20 \\
Saikai 139 & 100 & 20 & & 91 & 30 \\
Reiho & 100 & 77 & & 93 & 98 \\
TN1 & 96 & 83 & & 100 & 100 \\
\hline
\end{tabular}

${ }^{1)}$ Percentages of absorbance at $405 \mathrm{~nm}$ of the infected plants of each cultivar to that of TN1 $(=100)$.

resistance. As shown in Table 3, all the cultivars highly resistant to RWV, such as Ryoshaku 1 and Senbon Asahi, had low level of infections with RTSV. Reaction of Ginbozu varied among the four accessions and two of them had low infections with RTSV. On the other hand, RWV moderately resistant cultivars, such as Mizuho and Rikuu 20, had RTSV infections as high as did Reiho. As the degree of resistance to RWV of these cultivars was evaluated in the field tests, the resistance scores to RWV may also have reflected some factors other than the resistance to infection.

Fig. 1, shows that the RTSV resistance in Aichi Asahi, Kimmaze, Nishikaze and Saikai 139 was derived from that in Japanese traditional cultivar Takenari which was used as parent at an early stage of the japonica rice improvement program in Japan. 
Table 3. Resistance score against RWV and seedling infection with RTSV when inoculated by tungro viruliferous GLH in some japonica cultivars

\begin{tabular}{llcc}
\hline \hline Cultivar & $\begin{array}{l}\text { Acession } \\
\text { No. }{ }^{1)}\end{array}$ & $\begin{array}{c}\text { Resistance } \\
\text { to RWV }\end{array}$ & $\begin{array}{c}\text { Resistance to } \\
\text { RTSV (infected/ } \\
\text { inoculated) }\end{array}$ \\
\hline Ginbozu & 30164 & R & $11 / 19$ \\
Ginbozu & 40174 & & $3 / 25$ \\
Ginbozu & 40671 & & $1 / 21$ \\
Ginbozu & 80150 & $\mathrm{R}$ & $20 / 25$ \\
Ryoshaku 1 & 50078 & $\mathrm{R}$ & $0 / 21$ \\
Senbon Asahi & 40106 & $\mathrm{R}$ & $1 / 25$ \\
Chujo 2 & 50038 & $\mathrm{R}$ & $0 / 16$ \\
Fukumasari & 30278 & $\mathrm{R}$ & $4 / 19$ \\
Saikai 115 & 90713 & & $3 / 24$ \\
Mizuho & & $\mathrm{M}$ & $16 / 19$ \\
Rikuu 20 & 20236 & $\mathrm{MS}$ & $11 / 12$ \\
Sasanishiki & 20014 & $\mathrm{MS}$ & $16 / 25$ \\
Honenwase & 30269 & $\mathrm{MS}$ & $20 / 21$ \\
Tsukushibare & 90710 & $\mathrm{MS}$ & $15 / 22$ \\
Asominori & 90726 & $\mathrm{~S}$ & $21 / 23$ \\
Aichi Asahi & & $\mathrm{R}$ & $16 / 19$ \\
Reiho & & & \\
\hline A & & & \\
\hline
\end{tabular}

${ }^{1)}$ Accession No. of the Gene Bank, the National Institute of Agrobiological Resources (NIAR), Japan. All the seeds of the cultivars except for Aichi Asahi and Reiho were supplied by NIAR.

${ }^{2)}$ R: Resistant, M: Moderately resistant, MS: Moderately susceptible, S: Susceptible (SHIMURA et al. 1978).

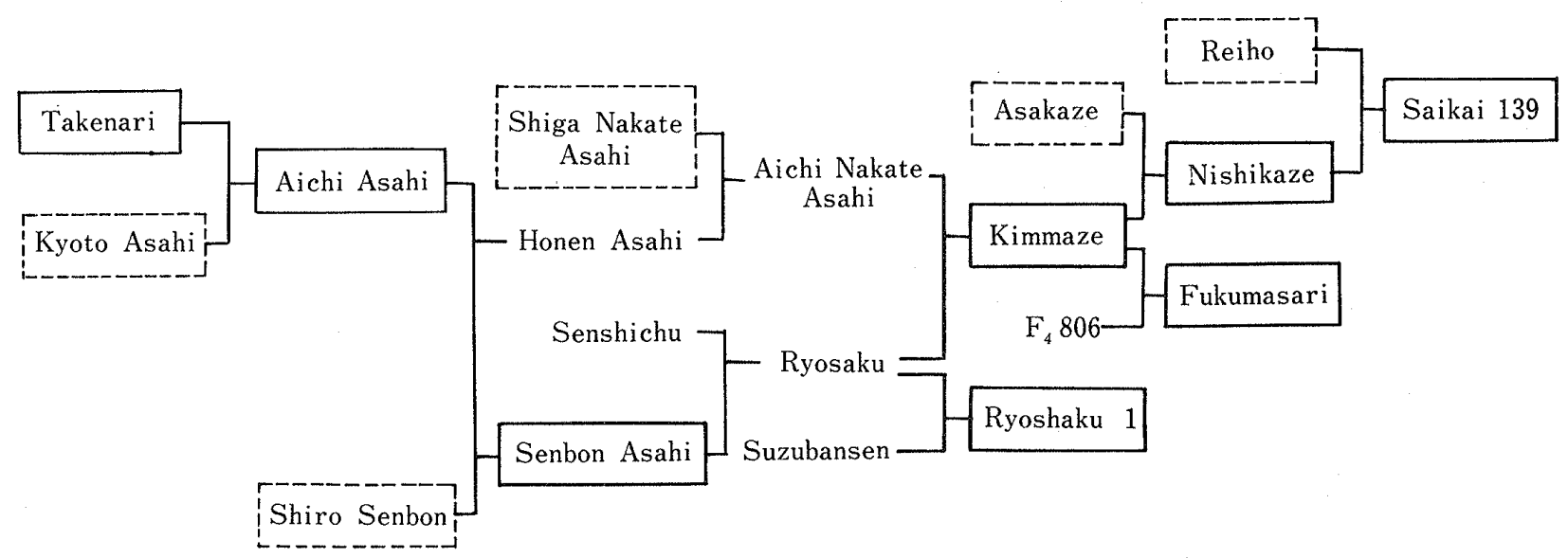

Fig. 1. Lineage of RTSV resistance in japonica cultivers tested. Note: $\square$ Resistant, ${ }^{--} \longrightarrow$ Susceptible.

Caltivars not marked were not téstêd. 


\section{Discussion}

Differentiation based on symptoms of tungro-inoculated seedlings whether they are infected with RTBV or RTSV alone, or with both RTBV and RTSV is practically impossible in the screening of cultivars for tungro resistance. ELISA was successfully applied to differentiate the type of infection.

In this study, RTSV infection rate was found to be low in four RWV-resistant cultivars, Aichi Asahi, Kimmaze, Nishikaze and Saikai 139. In the antibiosis test, the cultivars were susceptible to GLH, indicating that low RTSV infection in the cultivars is due to their resistance to RTSV. Besides the detection of viruses in inoculated plants, ELISA enabled to analyze the extent of virus multiplication in infected plants after measuring the absorbance of the reaction by spectrophotometry. Thus, all the four cultivars were also found to be resistant to RTSV multiplication.

The fact that RWV-resistant cultivars are also resistant to RTSV further supports the assumption made in earlier reports (Nishi et al. 1975, Hirao and Inove 1978, Sarto 1977) that RWV is similar to or identical with RTSV.

Although the RWV-resistant cultivars were infected with RTBV at a high rate and would be scored as "susceptible" rating in the screening for tungro resistance because of the tungro symptoms, they are expected to have low tungro incidence, as no dispersal of RTBV occurs in the absence of RTSV. Therefore, use of ELISA is indispensable in the breeding program for tungro resistance.

Hibino et al. (1988) described RTSV resistance in rice cultivars from the International Rice Research Institute (IRRI). All of these IRRI-bred (IR) cultivars belong to indica type and the RTSV resistance of these cultivars is derived from indica cultivar TKM6. Indica cultivar Pankhari 203 was found to be resistant to RTSV as well as to GLH using a GLH population which was adapted to Pankhari 203 (Habibuddin et al. 1990). In this study, we' identified several japonica cultivars having RTSV resistance which was derived from a traditional japonica cultivar Takenari in Japan. These japonica cultivars showed moderate resistance to RTSV, while the above-mentioned indica cultivars showed high resistance resulting almost no RTSV infection. Although genetic analysis is required to confirm whether the RTSV resistances of these indica and japonica cultivars are distinct from each other, the gene (or genes) for RTSV resistance of these cultivars is expected to be different due to the difference in the lineage of the cultivars and the degree of resistance.

Use of RWV-resistant cultivars would diversify the choice of gene sources for tungro resistance in rice breeding programs. Furthermore, the RWV-resistant cultivars are good gene sources in the rice breeding program for RTSV resistance, because some of them have already been considerably improved in their agronomic characteristics. In particular, they are expected to be a good donor of tungro resistance in order to improve japonica rice. On the other hand, RTSV-resistant cultivars, such as the IRRI-bred cultivars could be an alternative gene source for resistance to rice waika disease. The diversification of resistance sources is important in the breeding programs, because disease resistances have often been overcome due to occurrence of new strains of the pathogen. A new RTSV-resistant line which is de- 
veloped from the cross of Pankhari 203 in Malaysia and has favorable agronomic characteristics (HabibudDin et al. 1991), could be a good candidate for diversifying resistance sources.

\section{Acknowledgements}

The present study was conducted as a part of the Malaysian Agricultural Research and Development Institute (MARDI) and the Tropical Agriculture Research Center (TARC) Collaborative Program. We wish to thank Dr. SuPAAD M. A., Director of Rice Division, MARDI and Dr. T. TAKAHASHI, former Director of Research Division I, TARC for their assistance in the study. We also wish to thank all the staff members of the Entomology Section, MARDI for their technical assistance. Furthermore, we wish to thank Dr. H. Hibino, National Agriculture Research Center for reviewing the paper.

\section{Literature Cited}

AbU Kassim A. and Habibuddin H. 1986. Virus disease of rice and leguminous crops in Malaysia. Trop. Agric. Res. Ser. 19:33 39.

CLARK, M. F. and A. N. AdAMS 1977. Characteristics of the microplate method of enzyme-linked immunosorbent assay for the detection of plant viruses. J. Gen. Virol. 34:475 483.

HabiBudDIN, H., T. IMBE, and T. OMURA 1990. Survival and tungro transmission of green leafhopper biotypes, Nephotettix virescens (Homoptera: Cicadellidae) on resistant rices. Inter. Conf. on plant protection in the tropics:220. (abstract).

-, K. Hadzim, O. OThman, T. Imbe and T. Omura 1991. Selection of rice line Y1036 resistant to the green leafhopper and tungro disease. MARDI (Malaysian Agricultural Research and Development Institute) Res. J. 19:169 175.

Hibino, H., M. Roechan and S. Sudarisman 1978. Association of two types of virus particles with Penyakit Habang (tungro disease) of rice in Indonesia. Phytopathology 68:1412 1416.

- 1983. Transmission of two rice tungro-associated viruses and rice waika virus from doubly or singly infected source plants by leafhopper vectors. Plant Dis. 67:774 777.

-, R.D. Daquioag, P.Q. Cabauatan and G. Dahal 1988. Resistance to rice tungro spherical virus in rice. Plant Dis. 72:843 847.

HirAO, J. and H. INOUE 1978. Transmission efficiency of rice waika virus by the green rice leafhopper, Nephotettix spp. (Hemiptera:Cicadellidae). App. Ent. Zool. 13:264 273.

KobaYASHI, A., SUPAAD M.A. and OTHMAN O. 1983. Inheritance of resistance of rice tungro and biotype selection of green leafhopper in Malaysia. JARQ 16:306 311.

LiNG, K. C. 1972. Tungro disease. In "Rice virus disease" K. C. LING, International Rice Research Institute, Los Baõs, 93 105.

Nishi, Y., T. KimuRA and I. MaEJima 1975. Causal agent of "waika" disease of rice plants in Japan. Ann. Phytopathol. Soc. Japan $41: 223 \sim 227$.

Omura, T., S. Saito, T. Usugi and H. Hibino 1983. Purification of serology of rice tungro spherical and rice tungro bacilliform viruses. Ann. Phytopathol. Soc. Jpn. 49:73 76.

SAITO, Y. 1977. Interrelationship among waika disease, tungro and other similar diseases of rice in Asia. Trop. Agric. Res. Ser. 10:129 135.

- , H. Hibino, T. OMURA and T. UsUgi 1981. Transmission of rice tungro bacilliform virus and rice tungro spherical virus by leafhopper vectors. Proc. 5th Int. Cong. Virology: 213.

ShimURA, E., H. InOUe and M. IWASAKi 1978. Resistance of japonica varieties to rice waika disease and its donors. Proc. Assoc. Pl. Prot. Kyushu 24:3 5.

Takahashi, Y., T. Omura, K. Shohara and T. Tsuchizaki 1991. Comparison of four serological methods for practical detection of ten viruses of rice in plants and insects. Plant Dis. $75: 458 \sim 461$. 
日本型イネ品種のイネツングロ球状ウイルスに対する抵抗性

\author{
井辺時雄 ${ }^{1)} \cdot \mathrm{HABIBUDDIN}_{\mathrm{H}} \mathrm{H}^{2)} \cdot$ 岩崎真人 $^{3)} \cdot$ 大村敏博 $^{4}$ \\ (1)熟带農業研究センター，つくば市，テ 305 \\ 2)マレイシア農業開発研究所, マレイシア \\ 3)四国農業試験場，善通寺市，干 765 \\ 4)農業研究センター，つくば市， テ 305)
}

イネッングロ病の抵抗性遺伝子源を拡大するため, 本病の 1 ウイルスであるイネッングロ球状ウイルス rice tungro spherical virus；RTSV）と同一か極めて高い類縁関係にあるとされているイネわい化ウイルス（RWV）に対する 抵抗性品種について，イネッングロウイルス抵抗性を調查した。

イネわい化病抵抗性の愛知旭, 金南風, 二シカゼ, 西海 139 号の 4 品種㧍よび感受性品種のレイホウについて, RTSV，イネッングロ稈菌状ウイルス (rice tungro bacilliform virus；RTBV) 抢よび両ウイルスの媒介虫であ るタイワンツマグロヨコバイ (GLH) に対する抵抗性を検定した。ウイルス抵抗性は, 播種後 7 日の幼苗に, RTBV とRTSVの混合感染株で獲得吸汁させたGLHを接種して，感染苗率をELISAにより検定する方法（幼苗接種）と， 播種後 3 週間の苗に接種して,ELISAにおける吸光度を測定してウイルスの相対濃度を推定する方法によった。GLH 抵抗性は，播種後 7 日の幼苗にGLHの $1-2$ 令幼虫を着生させ, 3 日後の生存率に基づいて判定した.

愛知旭等RWV抵抗性の 4 品種は，幼苗接種においてRTBVには高率に感染したが，RTSVの感染率が低かった (Table 1).また, これらの品種にはGLH抵抗性(抗生作用)は認められなかった. RWV感受性のレイホウはRTSV にも台中在来 1 号 (TN1) と同様に感受性で西った。以上の結果，RWV抵抗性の 4 品種はRTSV抵抗性を有すると 結論された。

感染個体のウイルス濃度を検定した結果, 愛知旭等 4 品種は,レイホウおよびTN1よりRTSV濃度は低かった(Table 2).しかし, RTBV濃度はTN1と同程度に高かった。レイホウの両ウイルスの濃度はTN1並であった. 以上の結果 から，これら 4 品種はウイルス感染抵抗性のみならず，ウイルスの増殖に対する抵抗性を有すると考えられた。

上記 4 品種の他に 17 品種の日本型品種について幼苗接種によりウイルス感染率を調查した。 その結果, RWV抵 抗性が強と判定されている品種（志村ら 1978）は，いずれもRTSV抵抗性であった（Table 3)。また，これら品 種のRTSV抵抗性は日本の在来品種である竹成に由来することが明らかになった（Fig. 1）

以上の上うに，RWV抵抗性とRTSV抵抗性が一致したことは, RWVとRTSVとが同一か極めて高い類縁関係に あるとするこれまでの報告を支持するものである。

RTSVはGLHによるRTBVの伝搬に関与し,GLHは事前または同時にRTSVを吸汁しないとRTBVを伝搬しない (HIBINO et al. 1978)。したがって，RTSV抵抗性はRTSVのみならず，RTBVの伝搬を抑制することが期待され る.

HIBINo et al. (1978) およびHABIBUDDIN et al. (1990) はインド型イネのRTSV抵抗性品種について報告してい る.これらの品種との異同を分析する必要があるが, RWV抵抗性の日本品種は上記のものとは異なる新しいツング

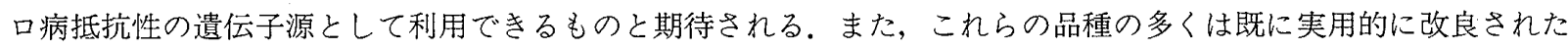
ものであるため，日本型イネの栽培地帯に扔るRTSV抵抗性の有望な遗伝子源であると考えられる。 